\title{
WORKING GROUP FOR PLANETARY SYSTEM NOMENCLATURE
}

\section{(GROUPE DE TRAVAIL POUR LA NOMENCLATURE DU SYSTEME PLANETAIRE)}

PRESIDENT

MEMBERS

CONSULTANTS
H. Masursky

K. Aksnes, M. Fulchignoni, G.E. Hunt, M. Ya Marov P.M. Milliman, D. Morrison, T.C. Owen, V.V. Shevchenko, B.A. Smith, V.G. Tejfel J.M. Boyce, G.E. Burba, A,M. Komkov,

Notice of the meetings held during the first two years of the triennium are included in volume XXA, p. 804-807 of this series. The Sixteenth meeting of the Working Group was held in Helsinki, Finland in July 1988, and the seventeenth meeting was held at Baltimore in August 1988 in connection with the General Assembly. At these meetings the following resolutions were proposed:

1. In proposing names for newly discovered satellites of the solar system it is recommended that first consideration be given to procedures al ready established within the IAU and that, where possible, confusing duplications with asteroid names be avoided.

2. An aquatic theme will be used for features identified during Voyager's encounter with Neptune and its satellites. Names from Greek or Roman mythology associated with neptune or Poseidon or the oceans will be used for new satellites. Surface features on Triton will be named for water creatures or sacred lakes, rivers, or seas (excluding Greek and Roman names). large ringed basins, if present, will be named for the primordial sea.

3. Additional features identified on Phobos by the Soviet mission will be named for characters and places in American and French Science fiction books about Mars.

4. The Small Bodies Task Group was activated under the chairmanship of Marciello Fulchignoni; other members include A. Brahic, Y.C. Chang, T. Gombosi, S. Isobe, L. Kasantfomoliti, D.F. Lupishko, D. Morrison, J. Veverka. This Task Group will propose names for features on the nuclei of Halleys and other comets, and additional features recognized on the surface of Phobos. We thank D. Morrison for serving as chairman pro tempore of this Task Group.

5. The name Colombo was proposed for a Saturnian ring feature.

6. Three names proposed for features on Mars and listed in volume XXA of the IAU Proceedings volume were dropped: Amet, Musmar, and Jeki. Other corrections to the lists of names printed in volume XXA of the IAU Proceedings are:

Incorrect Correct Incorrect Correct

Mars
Ecus Chasma
Echus Chasma
Cavi Frigores
Cavi Frigorēs

Jupiter,

$\frac{\text { Callisto: }}{\text { Holdr }}$

Uranian Satellites:

Höldr

$\begin{array}{llll}\frac{\text { Miranda }}{\text { Silicia Regio }} & \text { Sicilia Regio } & \frac{\text { Ariel }}{\text { Onagh }} & \text { Oonagh } \\ \text { Titania } & \text { Messima Chasma } & \text { Messina Chasma } & \text { Oberon Nommur chasma Mommur Chasma }\end{array}$

Names for 144 features were proposed in Volume $20 \mathrm{~A}$ of the IAU Proceedings: 32 names for Martian features, 20 names for features on Jovian satellites, 82 names for features on Uranian satellites, and 10 names for small Uranian satellites. In addition, we propose for adoption the following 124 names: 100 names for Martian features, 1 feature on the Martian satellite Phobos, 22 features on Callisto, and 1 feature on the Saturn's satellite Rhea: 


\section{Crater:}

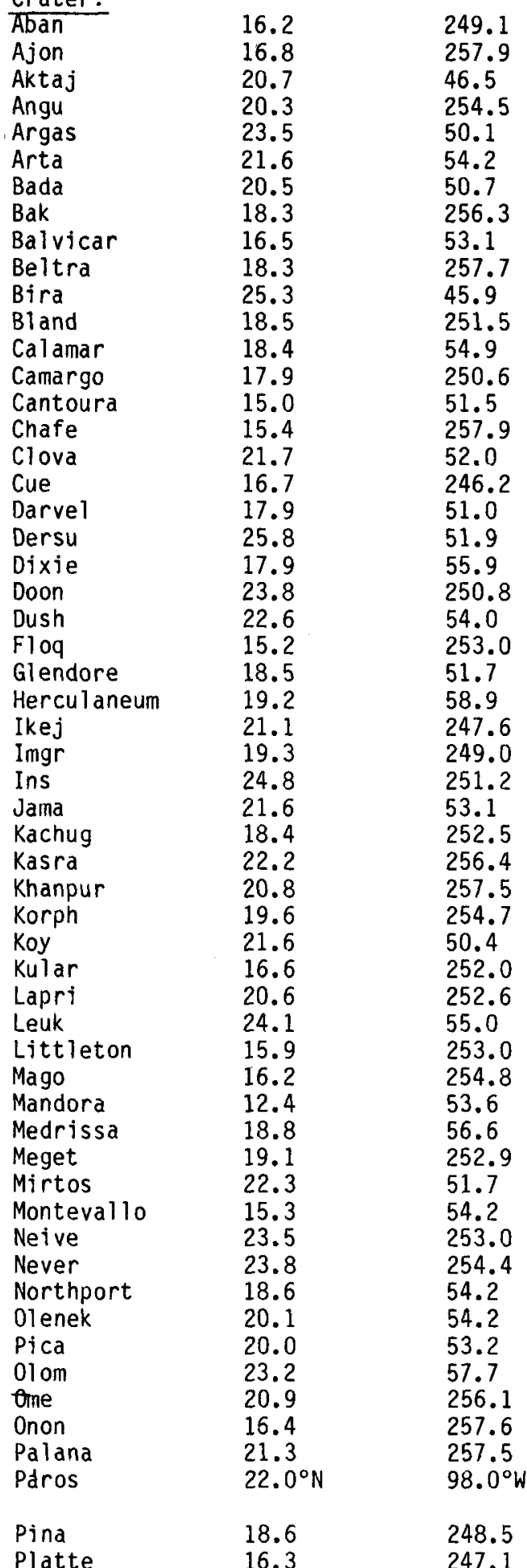

249.1

46.5

54.2

50.7

3.1

257.7

45.9

54.9

50.6

257.9

246.2

51.0

51.9

250.8

4.0

253.0

58.9

247.6

249.0

3.1

252.5

256.4

257.5

252.0

252.6

253.0

254.8

53.6

56.6

52.9

54.2

253.0

254.4

54.2

54.2

53.2

57.7

56.1

57.5

\section{MARS}

Town in USSR

Town in USSR

Town in USSR

Town in Zaire

Town in USSR

Town in USSR

Town in USSR

Town in Hungary

Town in Scotland

Town in Ireland

Town in USSR

Town in Missouri, USA

Town in Colombia

Town in Bolivia

Town in Venezuela

Town in Nigeria

Town in Quebec, Canada

Town in Australia

Town in Scotland

Town in USSR

Town in Georgia, USA

Town in Ontario, Canada

Town in Egypt

Town in Albania

Town in Ireland

Town in Italy

Town near USSR

Town in USSR

Town in Switzerland

Town in Tunisia

Town near Irkutsk, USSR

Town in Tunisia

Town in Pakistan

Town in USSR

Town in USSR

Town in USSR

Town in USSR

Town in Switzerland

Town in Maine, USA

Town in USSR

Town in Australia

Town in Algeria

Town near Irkutsk, USSR

Town in Crete (Greece)

Town in Alabama, USA

Town in Italy

Town in USSR

Town in Alabama, USA

Town in Yakut, USSR

Town in Chile

Town in USSR

Town in Japan

Town in Mongolia

Town in Kamchatka, USSR

Modern Greek village on island of same name

Town in Panama

Town in South Dakota, USA 
(Mars craters, cont.)

Pompei $\quad 19.0$

Poynting

$8.5^{\circ} \mathrm{N}$

Qibā

Sabo

Sevi

Sian

Sinda

Souris

Tarma

Tejn

Telz

Tepko

Thermia

Tibrikot

Tokko

Tokma

Tolon

Tomari

Torbay

Tuapi

Tumu ]

Turma

Ulu

Urk

Utan

Wum

Voza

Xui

Yalata

Yebra

Colles

Colles $\mathrm{Nil}$

Dorsum

Iamuna Dorsa

$20.4 / 21.5$

$50.1 / 50.4$

Fossa

Gigas Fossae $\quad 2.5 / 5.0^{\circ} \mathrm{N}$

$128.0 / 130^{\circ} \mathrm{W}$ $140^{\circ} \mathrm{W}$

Mensa:

$\begin{array}{lll}\text { Labeatis Mensa } & 25 / 26^{\circ} \mathrm{N} & 73.5 / 75^{\circ} \mathrm{W} \\ \text { Lunae Mensa } & 24 / 24.5 \mathrm{~N} & 61.5 / 63.5^{\circ} \mathrm{W} \\ \text { Nilokeras Mensae } & 28.5 / 34.5 \mathrm{~N} & 47 / 54.5^{\circ} \mathrm{W} \\ \text { Sacra Mensa } & 21 / 27.5^{\circ} \mathrm{N} & 63 / 73.5^{\circ} \mathrm{W} \\ \text { Tempe Mensa } & 27.5 / 28.5^{\circ} \mathrm{N} & 63 / 64^{\circ} \mathrm{W}\end{array}$

Ruined town in Italy

J.H. Poynting; first to theorize that small objects

orbiting sun were drawn into

it.

Town in Saudi Arabia

Town in USSR

Town in USSR

Town in USSR

Town in USSR

Town in Manitoba, Canada

Town in Peru

Town in Denmark

Town in East Germany

Town in Australia

Town in Greece

Town in Nepal

Town in russian USSR

Town in USSR

Town in Russian USSR

Town on Sakhalin Is., USSR

Town in Australia

Town in Nicaragua

Town in USSR

Town in USSR

Town in USSR

Town in Netherlands

Town in USSR

Town in Camaroon

Town in Solomon Islands

Town in Brazil

Town in Australia

Town in Spain

Classical albedo feature, Portus Nili at $38^{\circ} \mathrm{N}, 295^{\circ} \mathrm{W}$; a) so on 40292,3529735302

For albedo feature Iamuna

Albedo feature Gigas at $0^{\circ}$,

Albedo feature Labeatis Lacus, at $30^{\circ} \mathrm{N}, 75^{\circ} \mathrm{W}$

Albedo feature, Lunae Palus, at $17^{\circ} \mathrm{N}, 65^{\circ} \mathrm{W}$

Albedo feature Nilokeras, at $30^{\circ} \mathrm{N}, 55^{\circ} \mathrm{W}$

Albedo feature Sacra Insula, at $20^{\circ} \mathrm{N}, 57^{\circ} \mathrm{W}$

Albedo feature Tempe at $40^{\circ} \mathrm{N}$, $70^{\circ} \mathrm{W}$ 
(Mars, cont.)

Scopulus

Xanthe Scop.

$18.8 / 20.5$

$51.8 / 52.4$

For albedo feature Xanthe

Vallis:

$\begin{array}{llll}\text { Anio Vallis } & 37.8 / 38.4 \mathrm{~N} & 304 / 304.5^{\circ} \mathrm{W} & \begin{array}{l}\text { Classical river in Italy; } \\ \text { modern Aniene and Teverone } \\ \text { rivers } \\ \text { Classical river in Etruria; }\end{array} \\ \text { Clanis Valles } & 33.9 / 34.1^{\circ} \mathrm{N} & 301 / 302^{\circ} \mathrm{W} & \begin{array}{l}\text { present Chiana river, Italy } \\ \text { Classical river in Umbria, }\end{array} \\ \text { Clasia Vallis } & 33.3 / 34.6^{\circ} \mathrm{N} & 302 / 303.4 & \begin{array}{l}\text { Italy } \\ \text { Classical river in Sicily }\end{array} \\ \text { Hypsas Vallis } & 33.9 / 34.1^{\circ} \mathrm{N} & 301.7 / 302.4 & \end{array}$

CALLISTO

Crater:

Ahti

$42.0 ! N$

$23.0^{\circ} \mathrm{N}$

$34.0^{\circ} \mathrm{N}$

Ajleke

Aziren

Egres

Hijsi

Jyma 1

Kari

Kul

Ljekio

Maderatcha

$41.5^{\circ} \mathrm{N}$

$61.5^{\circ} \mathrm{N}$

$59.0^{\circ} \mathrm{N}$

$48.0^{\circ} \mathrm{N}$

$63.0^{\circ} \mathrm{N}$

$48.0^{\circ} \mathrm{N}$

$31.0^{\circ} \mathrm{N}$

Nirkes

$30.0^{\circ} \mathrm{N}$

Norov-Ava

$55.0^{\circ} \mathrm{N}$

Omol'

Reginn

Rongoteus

Rota

Tapio

Tontu

Tyll

Vanapagan

Vu-murt

Vutash

$42.5^{\circ} \mathrm{N}$

$40.5^{\circ} \mathrm{W}$

$54.0^{\circ} \mathrm{N}$

$28.0^{\circ} \mathrm{N}$

$31.0^{\circ} \mathrm{N}$

$28.0 \mathrm{~N}$

$43.5^{\circ} \mathrm{N}$

$38.5^{\circ} \mathrm{N}$

$22.0^{\circ} \mathrm{N}$

$32.0^{\circ} \mathrm{N}$

JUPITER

$103.5^{\circ} \mathrm{W}$

$101.5^{\circ} \mathrm{W}$

$178.0^{\circ} \mathrm{W}$

$175.5^{\circ} \mathrm{W}$

$169.5^{\circ} \mathrm{W}$

$120.0^{\circ} \mathrm{W}$

$118.5^{\circ} \mathrm{W}$

$124.0^{\circ} \mathrm{W}$

$162.0^{\circ} \mathrm{W}$

$95.5^{\circ} \mathrm{W}$

$163.5^{\circ} \mathrm{W}$

hunt

$115.0^{\circ} \mathrm{W}$

$118.5^{\circ} \mathrm{W}$

$90.5^{\circ} \mathrm{W}$

$107.0^{\circ} \mathrm{W}$

$110.0^{\circ} \mathrm{W}$

$110.0^{\circ} \mathrm{W}$

$100.5^{\circ} \mathrm{W}$

$165.5^{\circ} \mathrm{W}$

$158.5^{\circ} \mathrm{W}$

$171.5^{\circ} \mathrm{W}$

$103.0^{\circ} \mathrm{W}$

Finnish water god

Saami god of holidays

Estonian spirit of death

Karelian deity of bean harvest

Karelian deity of hunting

Estonian sky god

Ottar's ancestor

Komi wood spirit

Finnish god of grass

Saami sky god

Karelian patron of squirrel

Mordovian mistress of field

Komi wood spirit

Norse dwarf

Karelian deity of rye harvest

Deity of underground world

Finnish wood deity

Finnish god of housekeeping

Estonian epic hero

Estonian wicked giant

Estonian water spirit

Estonian water spirit

SATURN

Rhea

Crater

Tirawa

$35^{\circ} \mathrm{N}$

$150^{\circ} \mathrm{W}$

Great spirit of Pawnee tribe, Norh America; created first

men.

SMALL BODIES

Phobos
Dorsum

Kepler Dorsum
For Johannes Kepler, 1571-1630; German astronomer 